\title{
Response Characteristics of Inverted-base Asphalt Pavement Structure in Cold Area under Multi-axle Loads
}

\author{
Lin Wang*, Chao Shan, Chuanfeng Zheng \\ College of Construction Engineering, Jilin University, Changchun 130012, China
}

Corresponding Author Email: 18844548353@163.com

https://doi.org/10.18280/eesrj.070403

Received: 3 September 2020

Accepted: 24 November 2020

\section{Keywords:}

road engineering, multiaxial load, finite element analysis, asphalt pavement, graded macadam base course, response characteristics

\begin{abstract}
In cold areas, semi-rigid base asphalt pavement is prone to generate reflection cracks due to thermal contraction and dry shrinkage, and the base layer cracks can cause surface layer cracking and shorten the service life of the pavement. Aiming at understanding the response characteristics of asphalt pavement structure under multi-axle loads in cold areas, this paper took semi-rigid base asphalt pavement and inverted-base asphalt pavement as the research objects, and employed ANSYS to conduct finite element analysis on them to figure out the response characteristics of the asphalt pavement structure under the condition of different multi-axle loads and graded macadam base course. The research results showed that, the action of multi-axal loads increased the tensile stress of the base layer of the asphalt pavement and the tensile stress of the base layer of the semi-rigid base asphalt pavement, and increased the road surface deflection, which had resulted in insufficient bearing capacity of the pavement structure, and thus causing significant damages to the asphalt pavement; analysis of the response characteristics of the two types of asphalt pavement showed that, adding a graded macadam base course as the stress-absorbing layer is conductive to reducing the tensile stress of the base layer of the semi-rigid base asphalt pavement and effectively delaying or inhibiting reflection cracks generating on the pavement. The study of this paper provided a theoretical reference for the design and construction of asphalt pavement.
\end{abstract}

\section{INTRODUCTION}

In recent years, as the road traffic has increased rapidly in China, expressways are being constructed all over the country, and the semi-rigid base asphalt pavement is a dominant pavement structure type in these newly constructed expressways [1,2]. On the other side, with the development of the economy and the progress of the logistics industry, multiaxle vehicles have been widely used in transportation, which can cause serious damage to the asphalt pavement [3, 4], especially in cold areas; for example, semi-rigid base course often cracks due to thermal contraction, and the cracks would gradually grow and extend to the surface layer and form reflection cracks, and finally show pavement surface cracks and water damages $[5,6]$.

Jilin Province is a typical cold area in China, its complex terrain conditions have determined that many regions in Jilin are cold in winter and hot in summer, and the asphalt pavement in these areas has to suffer from extreme cold, intensive rainfalls, and continuous high temperature, which is a serious challenge to their service life $[7,8]$. Semi-rigid base is prone to thermal contraction and dry shrinkage cracks, and meanwhile the cracks in the base layer can lead to reflection cracks in the surface layer. Moreover, in rainfall seasons, water seepage repeatedly washes the base layer, causing base layer slurry concentration and erosion damages, etc. In some major highways and expressways, the actual traffic volume far exceeds the design standards; the increasing large vehicles have increased the roadbed diseases, the function of road surface has declined, and the quality of the roads has further declined $[9,10]$.

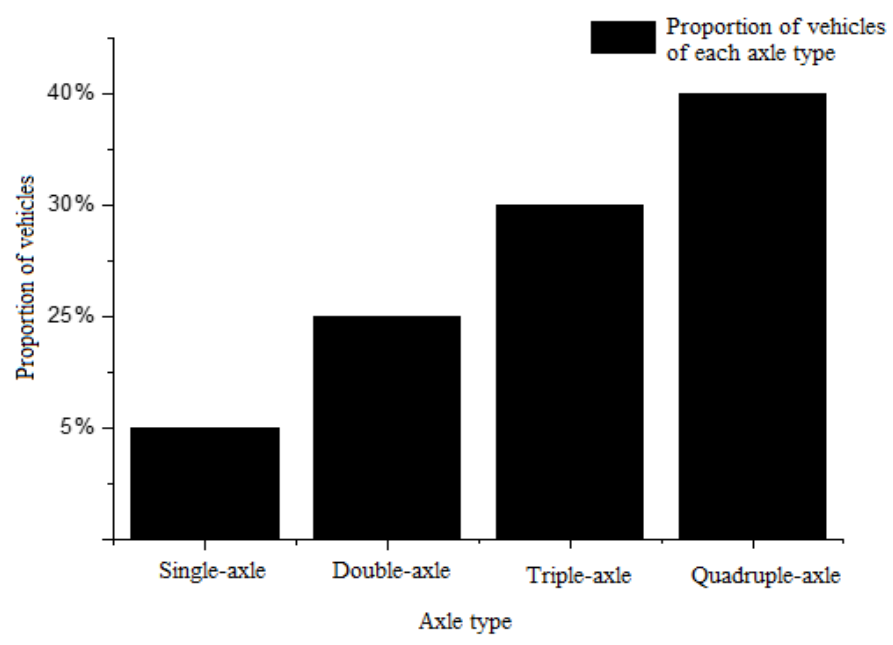

Figure 1. Statistics of vehicles with different number of axles on expressways of Jilin

Jilin Province is located in the middle of the three northeast provinces in China, and it is an important transportation junction in the area. The road disease types in Jilin mainly include low-temperature shrinkage cracking, fatigue cracking and permanent deformation [11]. In order to ensure the effective operation of expressway transportation network and 
the sustainable development of the logistics industry, after surveying the traffic conditions of expressways in Jilin province, this study simulated the mechanical response of the asphalt pavement structure under the action of multi-axle vehicle loads. Figure 1 shows the statistics of the vehicles with different number of axles on the expressways of Jilin Province.

\section{PARAMETERS OF MATERIALS OF EACH PAVEMENT LAYER}

Due to the high strength and rigidity characteristics, the expressway pavement in northeast China mostly adopts the semi-rigid base asphalt pavement structure, which can be divided into several parts: upper surface layer, middle surface layer, lower surface layer, base layer, sub-base layer and soil foundation. In order to simulate multi-axle loads, the pavement structure was divided into above-mentioned layers, and parameters of the materials of each layer were set according to the Specifications for Design of Highway Asphalt Pavement [12, 13], as shown in Table 1.

Table 1. Parameters of materials of each pavement layer

\begin{tabular}{ccccc}
\hline $\begin{array}{c}\text { Structure } \\
\text { layer }\end{array}$ & Material & $\begin{array}{c}\text { Thickness } \\
(\mathrm{cm})\end{array}$ & $\begin{array}{c}\text { Poisson's } \\
\text { ratio }\end{array}$ & $\begin{array}{c}\text { Compressive } \\
\text { modulus of } \\
\text { resilience (MPa) }\end{array}$ \\
\hline $\begin{array}{c}\text { Upper } \\
\text { surface layer } \\
\text { Middle }\end{array}$ & SMA-13 & 4 & 0.35 & 1400 \\
$\begin{array}{c}\text { surface layer } \\
\text { Lower }\end{array}$ & AC-25 & 10 & 0.25 & 1000 \\
$\begin{array}{c}\text { surface layer } \\
\text { Base layer }\end{array}$ & $\begin{array}{c}\text { Cement } \\
\text { stabilized }\end{array}$ & 30 & 0.25 & 1400 \\
$\begin{array}{c}\text { macadam } \\
\text { Lime }\end{array}$ & 20 & 0.25 & 600 \\
$\begin{array}{c}\text { Sub-base } \\
\text { layer } \\
\text { Soil }\end{array}$ & stabilized soil & - & 0.35 & 60 \\
foundation & - & & & \\
\hline
\end{tabular}

\section{ESTABLISHMENT OF FINITE ELEMENT MODEL}

Under normal conditions, the width of the expressway is between $20-50 \mathrm{~m}$, and the length ranges from a few kilometers to hundreds of kilometers. The expressway in service is generally under very complex stress state, so it's difficult establish a model with the size and stress state of the actual expressway in the simulation $[14,15]$. Therefore, the model had been simplified to a certain extent according to the research objectives, and the ANSYS finite element software was adopted to establish a $3 \mathrm{D}$ finite element model of the expressway with a size of $10 \mathrm{~m} \times 10.7 \mathrm{~m} \times 15 \mathrm{~m}$. In the model, $\mathrm{x}$ axis is perpendicular to the driving direction of the vehicle, $y$ axis is the longitudinal direction (along the road height direction), and the $\mathrm{z}$-axis is along the driving direction of the vehicle. The solid element SOLID 45 was adopted for modeling, and the layers were completely continuous. As shown in Figure 2, when modeling, the road pavement was divided into six parts: soil foundation, sub-base layer, base layer, lower surface layer, middle surface layer, and upper surface layer. The 3D models were built layer by layer from the soil foundation to the upper surface layer, and were meshed, as shown in Figure 3.
In the calculation process, the boundary conditions of the model were fully constrained by the road sub-base layer, and the displacement of the symmetry plane perpendicular to the $\mathrm{x}$ direction and the $\mathrm{z}$ direction was 0 . According to the Specifications for Design of Highway Asphalt Pavement, the double-circle vertical uniform load is usually adopted in the pavement design, the load density $\mathrm{p}=0.707 \mathrm{MPa}$, the equivalent circle radius $\delta=10.65 \mathrm{~cm}$, and the wheel center distance is $1.5 \mathrm{~d}$ [16].

However, in recent years, some research results showed that, during the driving process of the vehicle, the road surface contact shape of the vehicle tire is similar to a rectangular uniform load [17-20]. In this paper, all models took the standard axle loads for simulation, therefore, the contact surface between the tire and the road surface was converted into a rectangular uniform load with a rectangle size of $22.7 \mathrm{~cm} \times 15.6 \mathrm{~cm}$. The distance between two wheels was $31.95 \mathrm{~cm}$, and the distance between two adjacent axles was $1.4 \mathrm{~m}[21]$, as shown in Figure 4.

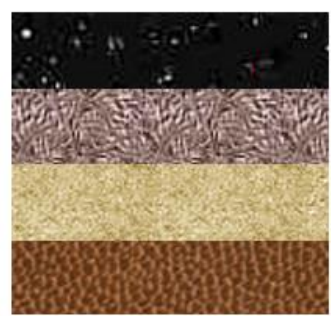

Surface layer

Base layer

Sub-base layer

Soil foundation

Figure 2. Pavement structure

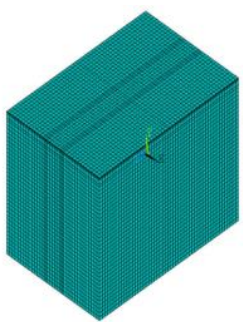

Figure 3. Model meshing
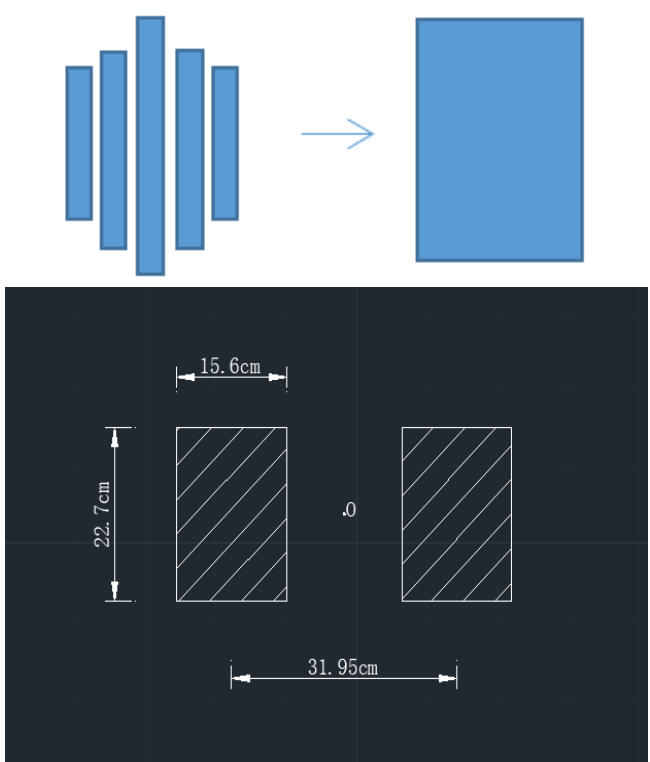

Figure 4. Simplified contact surface between tire and road surface ( $\mathrm{O}$ is the coordinate center) 
4. RESPONSE CHARACTERISTICS OF ASPHALT PAVEMENT STRUCTURE UNDER DIFFERENT AXLE TYPES

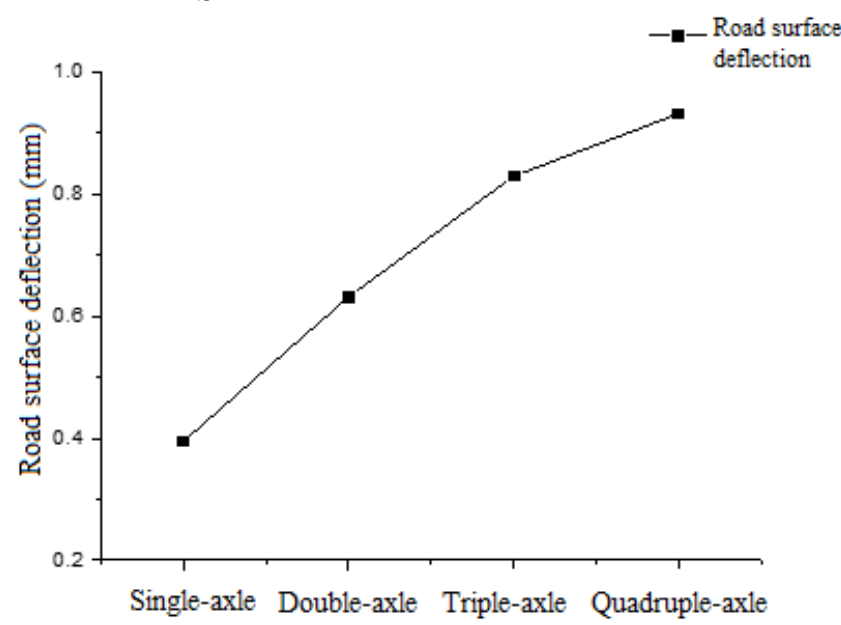

Figure 5. Impact of different axle types on road surface deflection

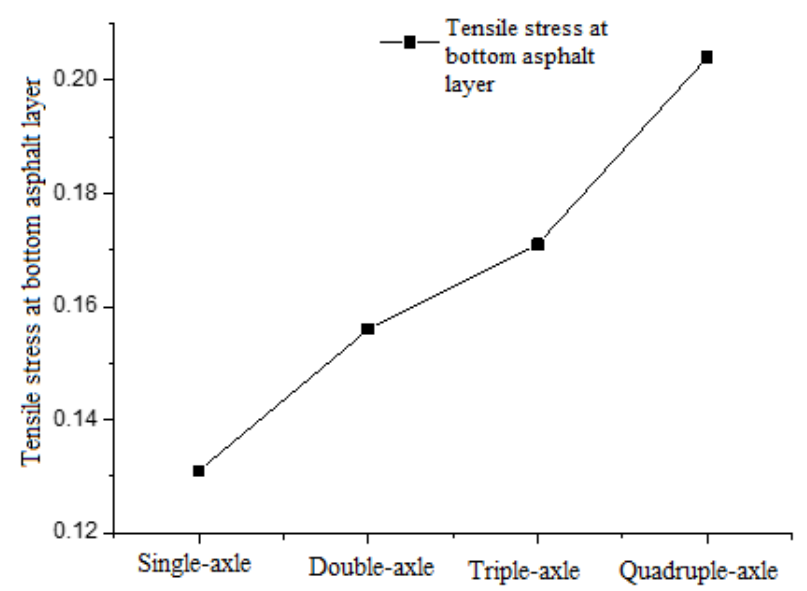

Figure 6. Impact of different axle types on the tensile stress at bottom asphalt layer

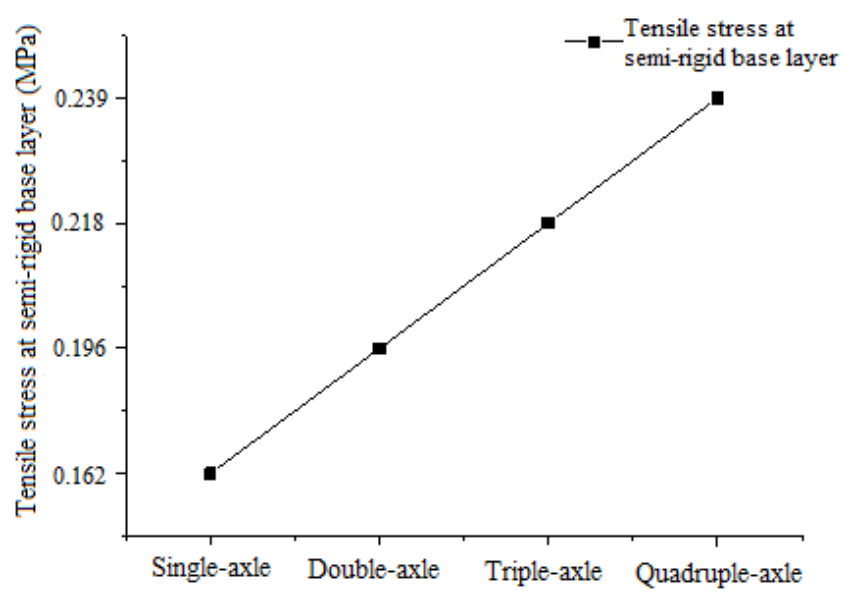

Figure 7. Impact of different axle types on the tensile stress at semi-rigid base layer

Based on the pavement structure system shown in Table 1, several 3D models were established for road surface under various conditions such as single-axle double-wheel, doubleaxle double-wheel, triple-axle double-wheel and quadruple- axle double-wheel, respectively; corresponding axle loads were applied on the road surface to obtain the change law of road surface deflection, tensile stress at the bottom asphalt layer, and the tensile stress at the semi-rigid base layer under the condition of different axle types, as shown in Figures 5-7.

According to Figure 5, the road surface deflection increased with the increase of the number of axles. Under the condition of double-axle two-wheel loads, the maximum road surface deflection increased by $60 \%$ compared with that under singleaxle two-wheel loads; under the condition of triple-axle twowheel loads, the maximum road surface deflection increased by $31.3 \%$ compared with that under double-axle two-wheel loads; under the condition of quadruple-axle two-wheel loads, the maximum road surface deflection increased by $12.3 \%$ compared with that under triple-axle two-wheel loads. It can be seen that, when other parameters remained unchanged, the road surface deflection under quadruple-axle double-wheel loads was the largest, the road surface deflection under singleaxle double-wheel loads was the smallest, and the increase trend tended to be slower. That is, under multi-axle loads, the road surface deflection of asphalt pavement increased, the bearing capacity of the pavement was reduced, and the service life of the asphalt pavement was seriously damaged.

According to Figure 6, as the number of axles increased, the tensile stress at the bottom asphalt layer gradually increased as well. Wherein, under the condition of double-axle two-wheel loads, the maximum tensile stress at the bottom asphalt layer increased by $19.1 \%$ compared with that under the single-axle two-wheel loads; under the condition of triple-axle two-wheel loads, the maximum tensile stress at the bottom asphalt layer increased by $9.6 \%$ compared with that under the double-axle two-wheel loads; under the condition of quadruple-axle twowheel loads, the maximum tensile stress at the bottom asphalt layer increased by $19.3 \%$ compared with that under the tripleaxle two-wheel loads. It can be seen that, when other parameters remained unchanged, the maximum tensile stress at the bottom asphalt layer was the largest under the quadruple-axle double-wheel loads, and the maximum tensile stress at the bottom asphalt layer was the smallest under the single-axle double-wheel loads; that is, the action of multi-axle loads gradually increased the tensile stress at the bottom asphalt layer, thus causing fatigue cracking to the road surface and aggravating the damage process of the asphalt pavement.

According to Figure 7, as the number of axles increased, the tensile stress at the semi-rigid base layer gradually increased as well. Wherein, under the condition of double-axle twowheel loads, the maximum tensile stress at the semi-rigid base layer increased by $20.9 \%$ compared with that under the singleaxle two-wheel loads; under the condition of triple-axle twowheel loads, the maximum tensile stress at the semi-rigid base layer increased by $11.2 \%$ compared with that under the double-axle two-wheel loads; under the condition of quadruple-axle double-wheel loads, the maximum tensile stress at the semi-rigid base layer increased by $9.6 \%$ compared with that under the triple-axle two-wheel loads. It can be seen that, when other parameters remained unchanged, the maximum tensile stress at the semi-rigid base layer was the largest under the quadruple-axle double-wheel loads, and the maximum tensile stress at the semi-rigid base layer was the smallest under the single-axle double-wheel loads, and the increase trend tended to be slower, that is, the action of multiaxle loads gradually increased the tensile stress at the semirigid base layer, which had accelerated the generation and development speed of the cracks. 


\section{IMPACT OF GRADED MACADAM BASE COURSE ON ASPHALT PAVEMENT STRUCTURE UNDER MULTI-AXIAL LOADS}

Table 2. Parameters of materials of the inverted-base asphalt pavement

\begin{tabular}{|c|c|c|c|c|}
\hline $\begin{array}{l}\text { Structure } \\
\text { layer }\end{array}$ & Material & Thickness $(\mathrm{cm})$ & $\begin{array}{l}\text { Poisson's } \\
\text { ratio }\end{array}$ & $\begin{array}{c}\text { Compressive } \\
\text { modulus of } \\
\text { resilience (MPa) }\end{array}$ \\
\hline $\begin{array}{c}\text { Upper } \\
\text { surface layer }\end{array}$ & SMA-13 & 4 & 0.35 & 1400 \\
\hline $\begin{array}{c}\text { Middle } \\
\text { surface layer }\end{array}$ & AC-20 & 6 & 0.25 & 1200 \\
\hline $\begin{array}{c}\text { Lower } \\
\text { surface layer }\end{array}$ & AC-25 & 10 & 0.25 & 1000 \\
\hline $\begin{array}{c}\text { Graded } \\
\text { macadam } \\
\text { base layer }\end{array}$ & $\begin{array}{l}\text { Graded } \\
\text { macadam }\end{array}$ & 15 & 0.25 & 450 \\
\hline $\begin{array}{l}\text { Semi-rigid } \\
\text { base layer }\end{array}$ & $\begin{array}{l}\text { Cement } \\
\text { stabilized } \\
\text { macadam }\end{array}$ & 20 & 0.25 & 1400 \\
\hline $\begin{array}{l}\text { Sub-base } \\
\text { layer }\end{array}$ & $\begin{array}{l}\text { Lime } \\
\text { stabilized } \\
\text { soil }\end{array}$ & 15 & 0.25 & 600 \\
\hline $\begin{array}{c}\text { Soil } \\
\text { foundation }\end{array}$ & - & - & 0.25 & 50 \\
\hline
\end{tabular}

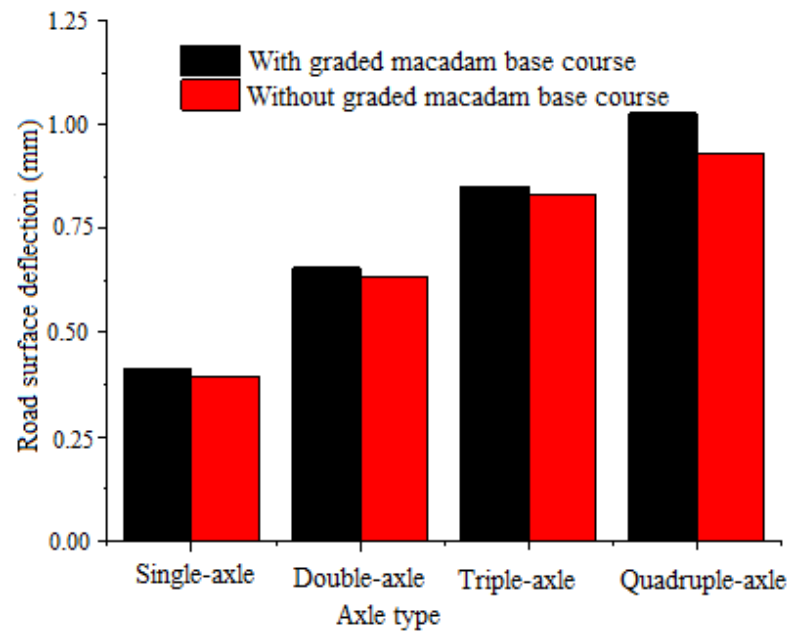

Figure 8. Comparison of road surface deflection of two types of asphalt pavement

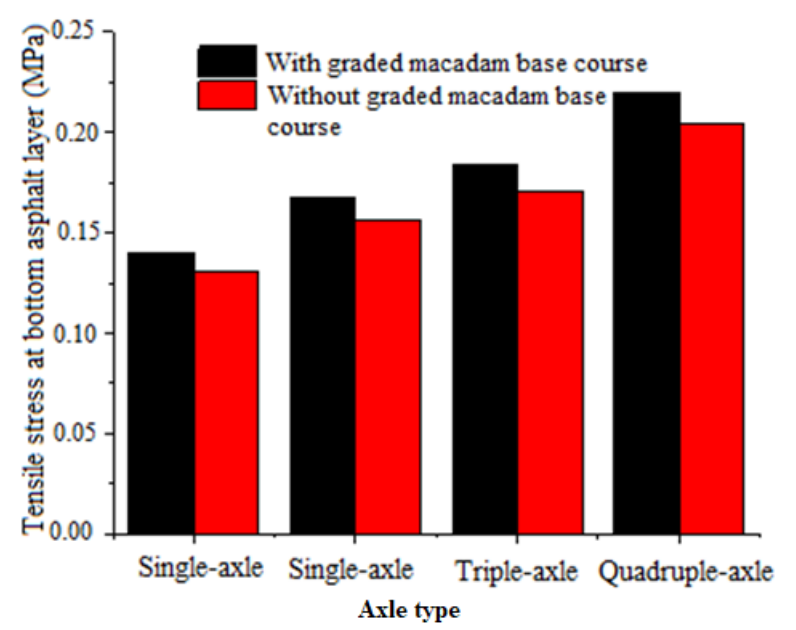

Figure 9. Comparison of tensile stress at bottom asphalt layer of two types of asphalt pavement

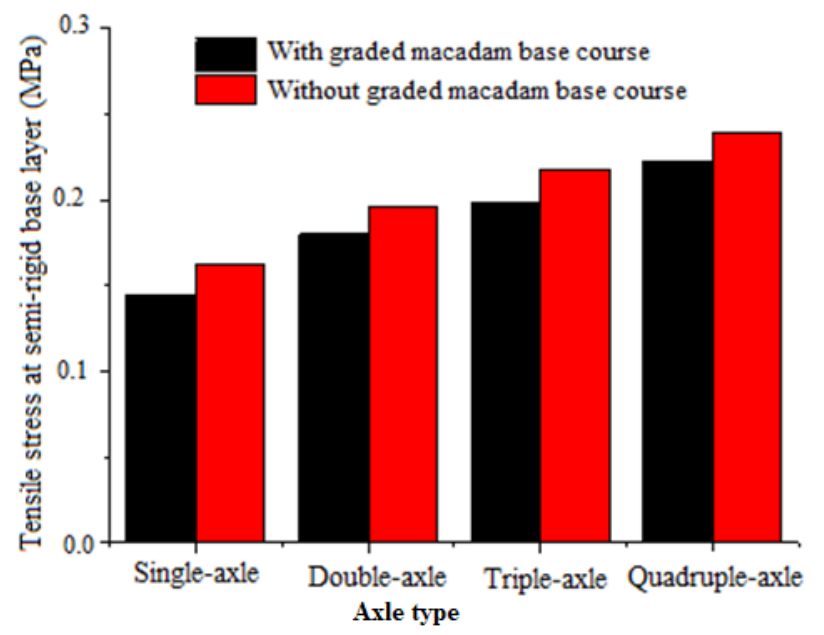

Figure 10. Comparison of tensile stress at semi-rigid base layer of two types of asphalt pavement

The shrinkage cracking of the base layer and the reflection cracks of the surface layer can cause serious early-stage damage to the asphalt pavement. In order to reduce such damage, researchers had developed the inverted-base asphalt pavement structure, which adds a graded macadam base course between the surface asphalt layer and the semi-rigid base layer and takes it as a stress-absorbing layer [22] to avoid excessive stress concentration and effectively delay the generation of reflection cracks [23].

To figure out the impact of the graded macadam stressabsorbing layer on the asphalt pavement structure, Wang et al. used Abaqus analysis software to construct models of inverted-base asphalt pavement structure with a graded macadam base layer, then, they used the singular isoparametric finite element method in the field of structural fracture analysis to study the generation of reflection cracks on the inverted-base asphalt pavement, and further estimated its fatigue life [22, 23]. Yang et al. proposed to use the graded macadam base course to alleviate the generation and development of cracks, and they conducted fatigue damage tests to discuss the mechanism of using graded macadam base course to prevent reflection cracks [24, 25].

In this study, the thickness of the graded macadam base course was set as $15 \mathrm{~cm}$. Table 2 lists the parameters of the materials of the inverted-base asphalt pavement. Then, the models were established using the same method, and the mechanical response of the inverted-base asphalt pavement and the semi-rigid base asphalt pavement was calculated according to Table 2, as shown in Figures 8-10.

According to Figure 8, for the four axle types, the road surface deflection of the inverted-base asphalt pavement with a graded macadam base course had increased by $4.6 \%, 3.6 \%$, $2.7 \%, 6.1 \%$ compared with that of the semi-rigid base asphalt pavement. According to Figure 9, for the four axle types, the tensile stress at the bottom asphalt layer of the inverted-base asphalt pavement had increased by $6.9 \%, 7.7 \%, 7.6 \%, 7.8 \%$ compared with that of the semi-rigid base asphalt pavement. According to Figure 8, for the four axle types, the tensile stress at the sub-base layer of the inverted-base asphalt pavement had increased by $11.7 \%, 9.9 \%, 9.5 \%, 8.1 \%$ compared with that of the semi-rigid base asphalt pavement. It can be seen that, when a graded macadam base layer was added as a stress-absorbing layer, the tensile stress of the bottom asphalt layer gradually increased, and the tensile stress of the sub-base layer gradually decreased accordingly, which reduced the probability of 
cracks in the base layer and sub-base layer, thereby helping to alleviate reflection cracks.

\section{CONCLUSIONS}

This study used ANSYS to simulate semi-rigid base asphalt pavement structure and analyzed the impact of graded macadam base course on the response characteristics of asphalt pavement structure under multi-axial loads, the research conclusions are:

(1) As the number of axles increased, the road surface deflection of the semi-rigid base asphalt pavement and the tensile stress at the bottom asphalt layer increased gradually, which accelerated the generation and development of fatigue cracking and reduced the service life of the asphalt pavement. When other parameters remained unchanged, under the condition of quadruple-axle two-wheel loads, the road surface deflection and the tensile stress at the bottom asphalt layer reached the maximum. Therefore, in pavement design, special attention should be paid to the mechanical response characteristics of the asphalt pavement structure under multiaxle loads.

(2) Compared with the semi-rigid base asphalt pavement, the road surface deflection and tensile stress of bottom asphalt layer of the inverted-base asphalt pavement with graded macadam base course as the stress-absorbing layer had increased, and the tensile stress of the semi-rigid base layer had decreased, which had avoided excessive stress concentration and effectively delayed the generation of reflection cracks. Therefore, the inverted-base asphalt pavement structure can be appropriately applied to the construction of expressways, and it can greatly reduce the probability of early-stage diseases such as cracks.

\section{REFERENCES}

[1] Dong, Z.J., Tan, Y.Q., Ou, J.P. (2013). Dynamic response analysis of asphalt under three-directional nonuniform moving load. China Civil Engineering Journal, 46(6): 122-130. https://doi.org/10.15951/j.tmgcxb.2013.06.003

[2] Dong, Z.J., Li, S.L., Wen, J.Y., Leng, Z. (2014). Realtime temperature measurement of asphalt pavement based on fiber BRAGG grating measuring technology. Journal of Traffic and Transportation Engineering, 14(2): $1-6$

[3] Papadopoulos, E., Santamarina, J.C. (2016). Analysis of inverted base pavements with thin-asphalt layers. International Journal of Pavement Engineering, 17(7): 590-601. https://doi.org/10.1080/10298436.2015.1007232

[4] Xu, X.Q., Li, H., Wu, C.H., Li, S.Q. (2018). Analysis on mechanics response of long-life asphalt pavement at moist hot heavy loading area. Advances in Materials, Machinery, Electronics II: Proceedings of the 2nd International Conference on Advances in Materials, Machinery, Electronics (AMME 2018) https://doi.org/10.1063/1.5033579

[5] Cyriaque, A.O., Sun, Z.Q., Tan, Y.Q., Lushinga, N. (2020). Finite-element simulation of instrumented asphalt pavement response under moving vehicular load. International Journal of Geomechanics, 20(3). https://doi.org/10.1061/(asce)gm.1943-5622.0001616

[6] Xiao, S., Neti, S., Suleiman, M.T., Naito, C. (2018). A Modeling approach of heat transfer of bridges considering vehicle-induced thermal effects. Journal of Applied Meteorology and Climatology, 57(12): 28512869. https://doi.org/10.1175/jamc-d-17-0315.1

[7] Ke, W.H., Chen, H.X., Lei, Y. (2019). Mechanical response of high-grade highway asphalt pavement in cold and high altitude area in Qinghai-Tibet Plateau. Journal of Chang'an University, 39(1): 34-43.

[8] Sullivan, B., Tran, K.T., Logston, B. (2016). Characterization of abandoned mine voids under roadway with land-streamer seismic waves. Transportation Research Record Journal of the Transportation Research Board, 2580(2580): 71-79. https://doi.org/10.3141/2580-09

[9] Lahucik, J.R., Schmidt, S.R., Tutumluer, E., Roesler, J.R. (2016). Characterization of cement treated base course using reclaimed asphalt pavement, aggregate byproducts, and macro-synthetic fibers. Paper presented at the Geotechnical Special Publication, Geo-Chicago 2016 https://doi.org/10.1061/9780784480137.050

[10] Ai, C., Xiao, C., Ren, D., Qiu, Y. (2016). Prediction of dynamic tensile strain at the bottom of asphalt concrete layer under FWD load. The 4th Chinese-European Workshop on Functional Pavement Design, CEW 2016. https://doi.org/10.1201/9781315643274-17

[11] Qamhia, I.I.A., Tutumluer, E., Ozer, H., Boler, H., Stolba A.J. (2020). Durability aspects of chemically stabilized quarry by-product applications in pavement base and subbase. Transportation Research Record, 2674(5): 036119812091911 . https://doi.org/10.1177/0361198120919113

[12] Wang, H., Dong, X. (2020) Analysis of the mechanical response of asphalt pavement with different types of base. Advances in Environmental Vibration and Transportation Geodynamics, 849-865. https://doi.org/10.1007/978-981-15-2349-6_56

[13] Zhang, L., Zhou, X., Wang, X. (2020). Research progress of long-life asphalt pavement behavior based on the RIOHTrack full-scale accelerated loading test. Chinese Science Bulletin, 65(30): 47-3258. https://doi.org/10.1360/TB-2020-0287

[14] Zhang, Y.L., Guo, C., Deng, Z.W. (2020). Analysis and applicability of road temperature stress behavior in cold area under large temperature difference. Paper presented at the IOP Conference Series: Earth and Environmental Science, $587 . \quad$ https://doi.org/10.1088/17551315/587/1/012059

[15] Jiang, Y., Zhang, Y., Deng, C., Yi, Y., Tian, T., Yuan, K. (2020). High-temperature rutting resistance of inverted asphalt pavement structure. Advances in Civil Engineering, 2020(2): 1-10. https://doi.org/10.1155/2020/1937508

[16] Tutumluer, E., Qamhia, I.I.A., Ozer, H. (2019). Field performance evaluations of sustainable aggregate byproduct applications. Lecture Notes in Civil Engineering, 3-23. https://doi.org/10.1007/978-981-13-6701-4_1

[17] Choudhary, R., Kumar, A., Rahman, G. (2019). Rheological and mechanical properties of bauxite residue as hot mix asphalt filler. International Journal of Pavement Research and Technology, 12(6): 623-631. https://doi.org/10.1007/s42947-019-0074-4

[18] Feng, L., Wu, C., Xu, X., Li, H., Liu, G. (2018). Analysis 
of strain law of structural layer of semi-rigid base asphalt pavement with graded crushed rock. IOP Conference Series: Materials Science and Engineering, 452(2): 022038 . https://doi.org/10.1088/1757899X/452/2/022038452/2/022038

[19] Francois, A., Ali, A., Mehta, Y. (2019). Evaluating the impact of different types of stabilised bases on the overall performance of flexible pavements. International Journalof Pavement Engineering, 20(8): 938-946. https://doi.org/10.1080/10298436.2017.1366766

[20] Kuchiishi, A.K., Antão, C.C.D.S., Vasconcelos, K., Bernucci, L.L.B. (2019). Influence of viscoelastic properties of cold recycled asphalt mixtures on pavement response by means of temperature instrumentation. Road Materials and Pavement Design, 20(sup2): s710-s724. https://doi.org/10.1080/14680629.2019.1633781

[21] Liu, F., Wu, C., Li, S., Xu, X. (2020). Study on strain test law of the semi-rigid base asphalt pavement. Paper presented at the IOP Conference Series: Materials Science and Engineering, 772: 012117. https://doi.org/10.1088/1757-899X/772/1/012117
[22] Wang, H.C., Huang, X.M. (2010). Research on crack propagation and fatigue life of granular base asphalt pavement. Journal of Wuhan University of Technology, 32(7): $\quad 65-68$. https://doi.org/10.3963/j.issn.16714431.2010.07.017

[23] Al-Qadi, I.L., Elseifi, M.A., Yoo, P.J. (2004). Pavement damage due to different tires and vehicle configurations. Final Report submitted to Michelin Americas Research and Development Corporation, 515.

[24] Yang, B., Chen, S.F., Wang, B.G., Li, Z.Z. (2006). Anticracking mechanisms of graded crushed stone cracking relief layer and the full-scale fatigue experiments. Journal of Highway and Transportation Research and Development, 23(12): 37-40. https://doi.org/10.3969/j.issn.1002-0268.2006.12.009

[25] Jau, W.C., Yang, C.T. (2010). Development of a modified concrete rheometer to measure the rheological behavior of conventional and self-consolidating concretes. Cement \& Concrete Composites, 32(6): 450460. https://doi.org/10.1016/j.cemconcomp.2010.01.001 